\title{
Ozone Transport
to
the San Joaquin Valley Baseline Observations from CABOTS
}

Adapted from "The California Baseline Ozone Transport Study (CABOTS)," by lan C. Faloona (University of California, Davis), Sen Chiao, Arthur J. Eiserloh, Raul J. Alvarez II, Guillaume Kirgis, Andrew O. Langford, Christoph J. Senff, Dani Caputi, Arthur Hu, Laura T. Iraci, Emma L. Yates, Josette E. Marrero, Ju-Mee Ryoo, Stephen Conley, Saffet Tanrikulu, Jin Xu, and Toshihiro Kuwayama. Published online in BAMS, April 2020. For the full, citable article, see DOI:10.1175 /BAMS-D-18-0302.1. espite marked decreases in pollution across the United States, the South Coast and San Joaquin Valley (SJV) of California remain the nation's only two "extreme" ozone $\left(\mathrm{O}_{3}\right)$ nonattainment areas. Further reductions of ozone in the West are complicated by significant background concentrations, whose relative importance increases as domestic anthropogenic contributions decline and the National Ambient Air Quality Standard (NAAQS) continues to be lowered. These background concentrations derive largely from uncontrollable sources including stratospheric intrusions, wildfires, and intercontinental transport.

Much uncertainty remains about the contributions of stratospheric and other transported ozone to surface concentrations in the SJV, which is the southern two-thirds of California's Central Valley. As a result, the California Baseline Ozone Transport Study (CABOTS), with its 2016 field campaign, observed the daily changes in ozone layering upwind of California and simultaneously the modified layering over the Central Valley itself.

\section{Sources of ozone}

Tropospheric ozone is photochemically produced by oxidation of carbon monoxide (CO) and volatile organic compounds (VOCs) in the presence of nitrogen oxides. The photochemical lifetime of ozone ranges from 1 week in the marine boundary layer to 1 year in the upper troposphere. The ozone directly upwind of the U.S. West Coast can therefore include anthropogenic contributions transported from East Asia and Europe, and even ozone that originated in the United States and subsequently circumnavigated the globe. This so-called "baseline" ozone constitutes a significant fraction of the ambient concentrations measured in the western 


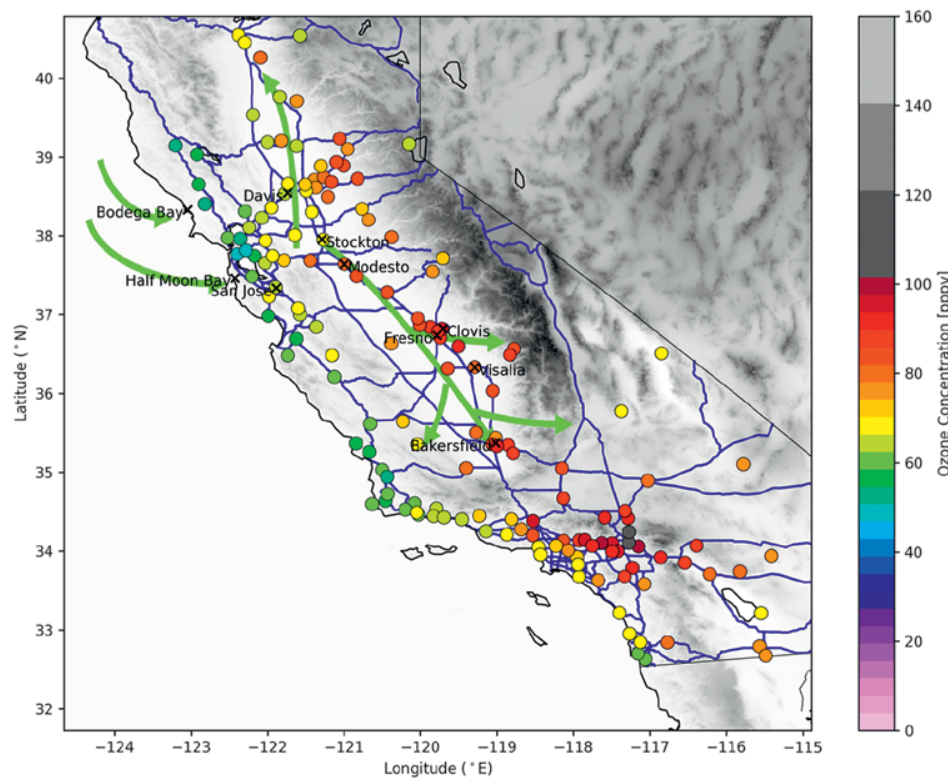

United States, particularly at high altitude locations.

The western United States is particularly susceptible to transported ozone because of several physical factors: the coastline promotes cross-tropopause transport of stratospheric ozone; in the lee of the Pacific subtropical anticyclone, both natural ozone and pollution subside from the middle and upper troposphere to the surface; and, especially in summer, dry convection entrains ozone above arid and/or high-elevation surfaces.

Episodes of ozone transported from Asia increase in frequency, peaking in the late spring (April-June), when the prevailing westerlies are strong and extratropical cyclone activity is greatest. During the summer monsoon, much of the Asian pollution is lofted into the upper troposphere $(>5 \mathrm{~km})$ by regional deep convection and then is transported eastward aloft; some of it is brought downward over California.

\section{Goals of CABOTS}

The aim of CABOTS was to produce an unprecedented dataset that might serve to promote

\footnotetext{
Overview of CAВОTS study domain and $*$ measurement platforms ranging from daily ozonesondes launched at the two coastal sites (Bodega Bay and Half Moon Bay) to the NOAA TOPAZ lidar in Visalia. The green and purple polygons represent the approximate domains surveyed by the NASA Alpha jet and Scientific Aviation, Inc., Mooney aircraft, respectively.
}

$4 *$ The 2016 ozone design values (ODV) across the state of California from the CARB surface air quality network. The ODV is defined as the 3-yr running mean of each year's fourth-highest maximum daily 8-h-average (MDA8) ozone concentration. Thin blue lines represent major highways, and thick green arrows show the typical daytime airflow near the surface during the warm season.

ensuing modeling studies. The dataset may help illuminate issues including (1) the fidelity with which air quality models represent ozone transport on synoptic, regional, and local scales in complex terrain; (2) the relative contributions of stratosphere-troposphere exchange, Asian emissions, and wildfires to the abundances and variability of ozone in and around California; and (3) the extent to which ozone from afar mixes down and affects NAAQS violations in the SJV.

Measurements of ozone vertical profiles were made from May to August of 2016, with near-daily ozonesonde profiles collected at two sites along the coast and an ozone lidar dataset collected in Visalia, in the SJV. A radar wind profiler and radio acoustic sounding system (RASS) at the Visalia airport provided measurements of virtual temperature profiles up to $1-1.5 \mathrm{~km}$ and winds up to $4 \mathrm{~km}$.

In addition, aircraft measurements from Fresno to Bakersfield and out to the coast characterized the evolution of ozone layering in the lower atmosphere $(<1,500 \mathrm{~m})$ over the course of the entire diurnal cycle. Furthermore, the Alpha Jet Atmospheric Experiment (AJAX) of

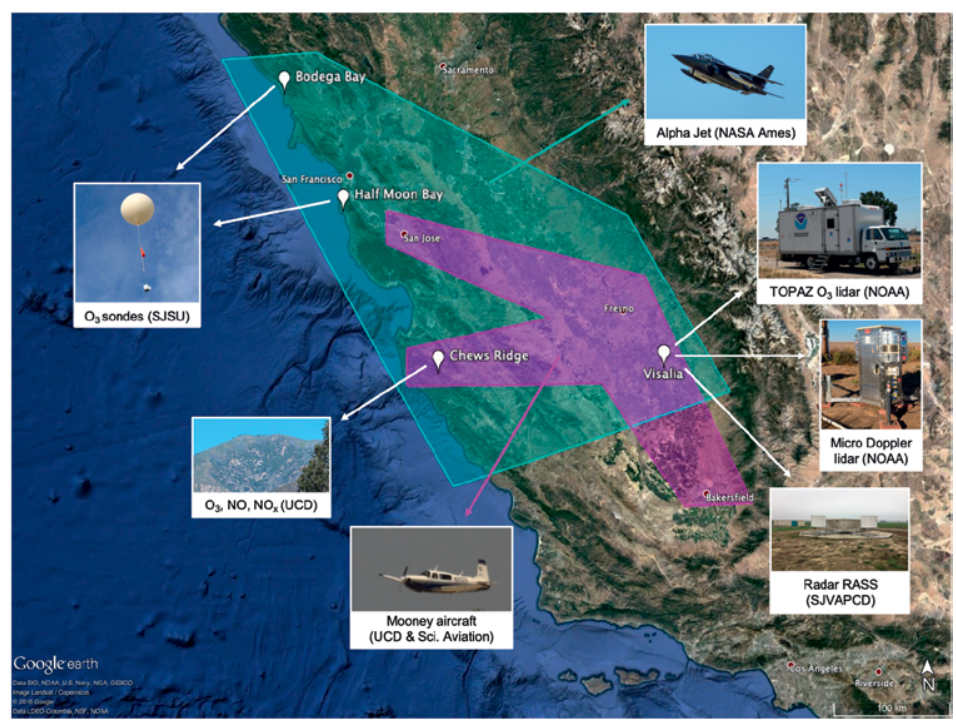




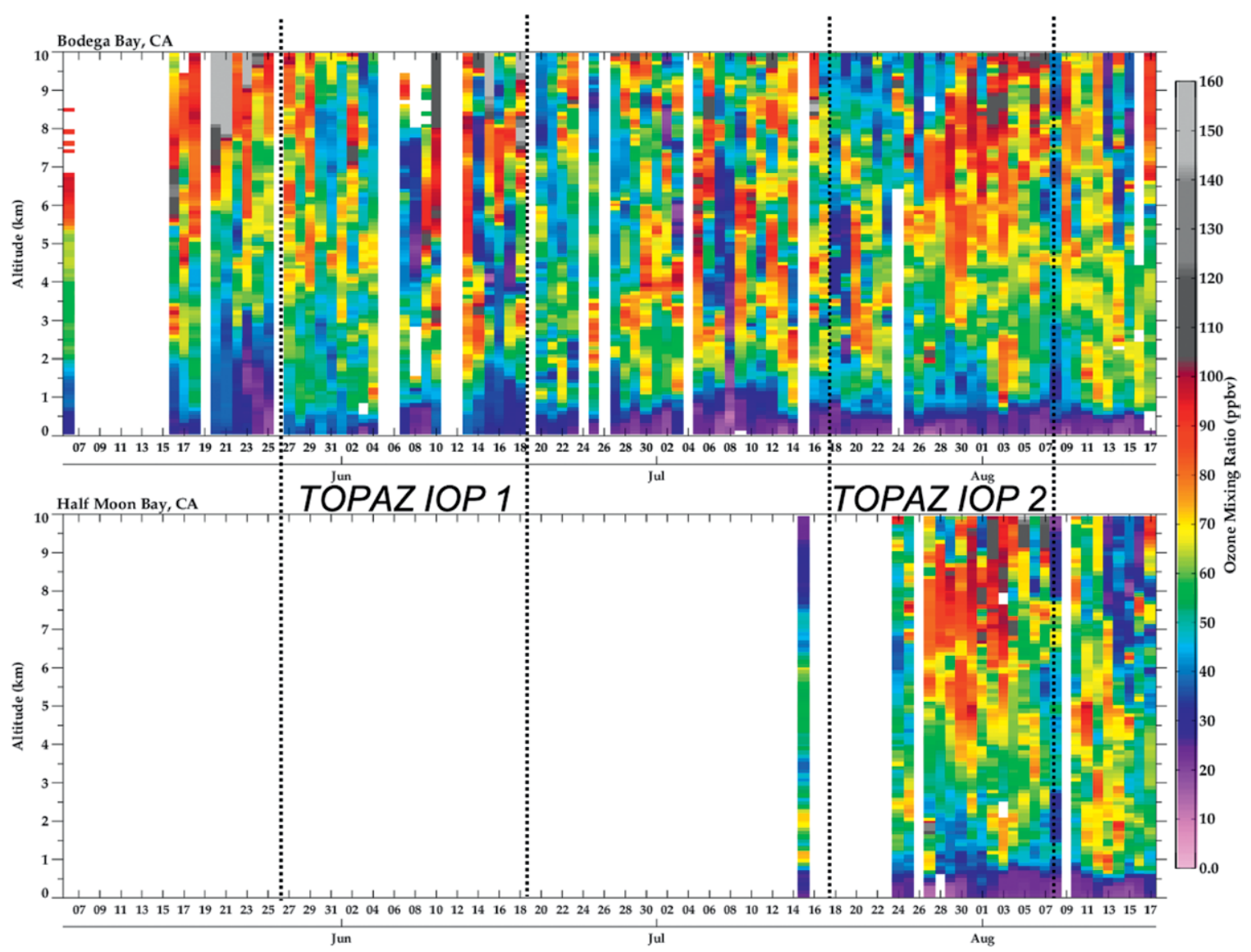

the NASA Ames Research Center performed its regular missions to measure ozone and greenhouse gases, such as ozone, carbon dioxide $\left(\mathrm{CO}_{2}\right)$, methane $\left(\mathrm{CH}_{4}\right)$, and formaldehyde (HCHO) over California and Nevada.

In addition to the usual ozone data collected at nearly 80 California Air Resource Board surface sites in Central and Northern California (with 25 of them in the SJV Air basin), the University of California, Davis, made ozone, NO, and $\mathrm{NO}_{\mathrm{x}}$ measurements at a mountain observatory on Chews Ridge (elev. $1,550 \mathrm{~m}) 40 \mathrm{~km}$ southeast of Monterey.

\section{A sampling of CABOTS measurements} Daily ozonesonde data from the coastal sites exhibited ozone concentration undulations in the mid- to upper troposphere with 3-5-week periodicities, indicating the importance of day-to-day variability for accurately constraining the oxidant boundary conditions along the North American inflow.

Onshore winds usually only penetrate to the Central Valley at breaks in the Coast Range because the marine atmospheric boundary layer
* Ozonesonde profiles measured at (top) Bodega Bay and (bottom) Half Moon Bay during CABOTS (vertical dashed lines indicate TOPAZ IOPs).
(ABL) tends to be well below the height of the coastal mountains. A commonly used chemical transport model captured the strong gradients at the top of the marine ABL. Between 1 and $3 \mathrm{~km}$, however-in air that likely influences the surface ozone levels inland the most-the observed daily standard deviation is $\sim 60 \%$ greater than is captured in the model. Frequent ozone concentrations high enough for air quality exceedances-well above 60-70 ppb (mean plus one standard deviation)-were found at $1.5-\mathrm{km}$ altitudes and above at the coast.

In general, the lidar data show the rich textures of the air above the valley with frequent episodes of high ozone concentrations advected overhead in the upper troposphere as well as accumulations of ozone in the ABL and the buffer layer above (up to $2-2.5 \mathrm{~km}$ ).

The southern Sierra Nevada can block the flow, which does not stagnate as much as recirculate the air within the valley buffer layer. Higher up, in the free troposphere, the mountain-impeded flow weakens the Coriolis force, and above the reach of the mountainvalley thermal circulation air is pushed down 
the background pressure gradient, which is directed more or less down-valley, driving southeasterly winds aloft. There is little wind shear across the well-defined thermodynamic capping inversion as the daytime up-valley flow persists throughout the ABL and buffer layer.

The valley atmosphere's layering was also evident. The difference between the baseline composition of the air moving onshore at the coast and the air heavily influenced by California's Central Valley was clear. In one instance, the ABL at Visalia appears to be around $800 \mathrm{~m}$ and the buffer layer seems to extend up to about $2,500 \mathrm{~m}$. The long chemical lifetime and abundance of methane from the valley's agriculture and oil production clearly shows the triple layering of the valley $\mathrm{ABL}$; local methane levels were enhanced by 100150 ppbv over the baseline observed offshore.

The overnight data show ozone depletion in a shallow nocturnal boundary layer due to nitrate production and dry deposition, followed at daytime by a well-mixed boundary layer conducive to the buildup of ozone, but only growing to an average depth of about $500 \mathrm{~m}$ above the surface. Elevated ozone between 500 and 2,500 m suggested that ABL air is lofted into the buffer layer above due to daytime slope flow along the flanks of the valley.

With 440 hours of ozone lidar profiles over Visalia, more than 100 coastal ozonesondes, and several targeted airborne surveys, the CABOTS dataset should provide novel constraints on modeling efforts, ultimately producing insights into the transport and mixing contributing to high ozone levels found in the San Joaquin Valley and other large valleys around the world. The detailed observations may challenge future attempts to model the episodic trans-Pacific transport and the impact distant ozone sources have on air quality in the mountainous West. $\bullet$ •

\section{METADATA}

BAMS: What would you like readers to learn from this article?

Ian Faloona: I think this article presents a nice overview of the mesoscale flow over the complex terrain of Central and Northern California, and I would like readers to become more appreciative of the global nature of air pollution. The field of air quality was once considered in terms of emissions and receptors within "air basins," but as our knowledge of the global nature of greenhouse gases in terms of climate change has developed, I believe that we have similarly become more and more aware of the global aspects of many air pollutants in general.

BAMS: What started you on the path to this experiment?

IF: Some colleagues from the UC Davis Air Quality Research Center and I became interested in long-range transport of air pollution to California and how it might be best sampled along the coastal mountains where local emissions might be minimal and the surface was well above the strong temperature inversion of the marine boundary layer. We eventually found the site on Chews Ridge where a group of renegade astronomers had been operating an off-the-grid observatory with the Monterey Institute for Research in Astronomy. They allowed us to build a climate monitoring site collocated with their observatory (the Oliver Observing Station). Some airborne work for the San Joaquin Valley Air Pollution Control District allowed us to link the inflow at the coast to air quality issues within the leeward valley.

BAMS: What surprised you the most about your findings in CABOTS?

IF: The first thing that surprised me about the data we collected for CABOTS was how deep the daytime up-valley flow was $(\sim 1.5 \mathrm{~km})$, but how shallow the convective boundary layers tended to be $(\sim 0.5 \mathrm{~km})$. The scale interactions that need to be taken into account when analyzing boundary layers among the complex terrain of California make it a great place to study in meteorology. But the other major discovery that came out of this work was the evidence we found of significant NOx emissions from certain agricultural regions in the San Joaquin Valley. For instance, we found that the agricultural region between Fresno and Visalia was responsible for as much NOx emitted to the valley atmosphere as from all the mobile sources in the CARB inventory across the three-county region.

BAMS: What was the biggest challenge you encountered in the project?

IF: The sensible heat at the Fresno airport. Our airborne deployments attempted to target high ozone episodes, which are best forecast by their correlation with ambient temperatures. I like to tell my students that I am a chaser of extreme weather. It just so happens that the weather features most important to air quality are heat waves. Heat waves are extremely easy to catch, and can be brutal in their persistence. Some days we observed temperatures in the plane on the tarmac of $>115{ }^{\circ} \mathrm{F}$, which made it challenging to keep the equipment up and running. I remember dragging bags of ice in and out of the plane covered in sweat, and still having the instruments give up in heat exhaustion before one of our midday flights. 